\title{
Study on the Application of Traditional Calligraphic Art in Graphic Design
}

\author{
Yaojie Guo \\ School of Art and Design \\ Huanghe Science and Technology College \\ Zhengzhou, China \\ e-mail: 45655942@qq.com
}

\begin{abstract}
Calligraphy is the model of Chinese traditional art, but it needs case study to better integrate it into the graphic design, apply it in graphic design, and thus reflect the cultural connotation of graphic design works, enhance and improve the graphic design to the international level. In this way, we can see the influence of the traditional calligraphic art on graphic design more clearly, know how designers get calligraphy prototypes from traditional calligraphic art and transform them into desired design elements. It requires that designers shall set the design style, obtain calligraphic art prototypes, capture calligraphic art elements and transform them into design elements and then apply them into design. It is embodied in different forms in the logo design, packaging design, poster design, graphic design and etc.
\end{abstract}

\section{Keywords—calligraphic art; graphic design; case study}

\section{THE APPLICATION OF THE TRADITIONAL CALligraphic ART IN LOGo DESIGN}

Graphic design has moved into an era of diversified development period. The designers of modern logo design constantly absorb creative inspiration from the Chinese traditional art elements, which has not only developed the Chinese traditional culture, but also reflected the combination of traditional culture and modern design. As a representative of traditional art, the calligraphic art is widely used in logo design. Culture is the soul of design. The cultural background comes first in designing works. In other words, what is the connotation that designers want to express through the design. The connotation represents the culture designers want to express through their works.

In logo design, symbol is regarded as appearance and emotion as connotation. It is an intermediary to combine them. Only by accepting diversified thought and traditional culture, can the logo design works stand the test of time, and thus surpass the mark itself and carry spiritual connotation. Logo design is basically composed of graphics, text and color etc.. Chinese character is one of the most ancient characters, and has a very deep cultural connotation and artistic charm. As a traditional art, the art of calligraphy and its decoration can arouse a strong sense of national pride and bring visual impact. Designers could absorb the essence from traditional culture. For example, we can see the traditional calligraphy elements from the logo of 2008 Beijing Olympic
Games, the logo of Paralympic Games, the logo of 2010 Shanghai World Expo and the logo of Sydney 2000 Olympic Games.

China's biding logo for the Olympic Games has five brightly colored circles, corresponding to the Olympic rings and representing the five continents. The inspiration of the biding logo sources from the Chinese traditional culture. It applies the characteristics of the brush writing in cursive script, and is written at one sketch, and all rings link with one another. We also can find this kind of art type in the logo of 2008 Olympic Torch Relay, the logo of 2008 Olympic Volunteers, the logo of 2008 Olympic Games Environment, the logo of Olympic Cultural Activities and the logo of 2008 Beijing Paralympic Games. These design works in Chinese traditional style are widely recognized in the world.

The logo of Beijing 2008 Paralympic Games "heaven and earth and man" was designed by Associate Professor Paul Liu of Central Academy of Fine Arts. He integrated Chinese characters, calligraphy and the spirit of the Paralympic Games and highlighted the simplicity of the logo. This design intensively shows the traditional culture and the spirit of modern Olympic Games and has a profound Chinese traditional cultural deposits. His design applies traditional calligraphic art elements and transforms Chinese character “之” into a modern element, composed of three colors, red, blue and green. The words "Beijing 2008" is written in calligraphic font. The graphics in calligraphic font shows us a human shape in motion. The designer enhances the aesthetic taste and gets a better visual effect through skillful combination and arrangement of dots and lines. The simple and pure design work is the concentration processing of information and the refining expression of the content, which highlights its integrity and coordination, and at same time accord with the seal of the Beijing Olympic Games.

The logo of Shanghai 2010 World Expo "you, me, him/her" was designed by Designer Shao Honggeng of Jiangsu Yancheng. The logo design selected Chinese character "世" as creative element and skillfully combine the number "2010". The logo of Shanghai 2010 World Expo, by using the calligraphic art elements, fully reflects the integration of internationalization and multiculturalism. The designer has integrated the Shanghai Expo's philosophies of 
"understanding, communication, gathering and cooperation" into Chinese traditional culture, which conveys the peopleoriented pursuit of the Shanghai World Expo. The designer uses art means in his conception of design and makes the work full of interest and originality. It suggests that Chinese people make unremitting efforts to carry forward the traditional culture while we are engaging in the world.

\section{THE APPLICATION OF THE TRADITIONAL CALLIGRAPHIC ART IN PACKAGING DESIGN}

Packaging is the comprehensive reflection of the brand concept, product characteristics and consumer psychology, is the communication bridge between products and consumers, is the communication media of product information, and it can directly stimulate consumers' purchasing desire. Packaging design refer to the design of product containers, other packaging structures or appearance. The art of calligraphy, as a unity of practicality and artistry, is widely used in packaging design. Our design level is relative lower compared with developed countries. In order to reach the international level, we should combine the traditional culture with modern design, and create works with our national characteristics in learning from international experience. Some good packages show their value and also reflect the brand image and connotation. It can better reflect the characteristics of regional culture in the packaging of commodities by integrating various calligraphic arts in different ages into packaging design.

Japanese create the style of packaging design with Japanese characteristics by integrating “書道” (Japanese call calligraphy “書道”. Chinese calligraphy was spread to Japan as early as Tang Dynasty. Japanese have created their own calligraphic art on the basis of repeated exploration and practice.) into the design. The Japanese packaging can fully embody the characteristics of Japanese culture. The calligraphic fonts are widely used in Japanese packaging design, and creating a harmonious relationship between the packaging and calligraphy. With the graphics and text in Japanese traditional style, the design works could reflect the unique Japanese aesthetic taste and their national culture. At same time, they have created the Japanese style packaging design. Although there is a gap between our design level and that of developed countries, Chinese designers have realized that "things only from national public can be recognized by the world". The international exchanges become increasingly faster. Chinese packaging designers value the integration of traditional culture and arts, but they ignore the essence of design. Designers simply "put" the traditional elements into packaging design, however they do not integrate them into one. We can make up for the shortcomings by integrating traditional calligraphic art into the packaging design.

In recent years, some outstanding packaging design works have reflected the artistic charm of calligraphy, gradually forming a design culture with Chinese characteristics. In our country, many tea packaging, wine packaging, food packaging, book packaging and etc. have applied calligraphic decorativeness and artistry, and show strong Chinese charm, and let people experience the cultural connotations through packaging design. For example, the famous designer Chen Xiaolin applied the Chinese calligraphic art into his design works for Swellfun spirit and Huanghelou spirit. The simple and bright calligraphic art highlights the theme and reveals strong local flavor. Chinese tea packaging also reflects the unique charm of calligraphic art in design. The USB flash disk packaging with the unique ethnic flavor are particular arresting and eye-catching. Yang Shouyun, a boss of a tea house in Fujian, packs Taiwan tea with packaging with Chinese traditional calligraphy and bamboo slip pattern, which facilitated the most beautiful and cultural cross-strait tea ceremony.

The famous designer Chen Xiaolin has created a serious of packaging designs for "Swelfun" spirit and Huanghelou spirit. The "Swelfun" spirit packaging with full-bodied traditional oriental cultural connotation and simple modern technique has won the first place of the 30th Mobius Award in wrapper class and the award of general comment list. His design fully reflects the characteristic of regional culture, strengthens and implements the environmental-protection packaging consciousness, and highlights design originality. The designer applies calligraphy fonts into the design, use the writing to convey accurate information. At the same time, the packaging design applies new technologies and new materials, reflecting its environmental protection function. His packaging design highlights the Chinese long spiritmaking culture. On the basis of the local cultural characteristics, the design passes down the spirit-making culture, at the same time show Chinese traditional cultural characteristics.

\section{THE APPLICATION OF THE TRADITIONAL CAlligraphic ART In The Poster Design}

It can show the artistry of poster to integrate the traditional art of calligraphy into poster design. It can reflect the cultural connotation of the design works better by combining ink elements in calligraphic art with poster design. "Poster is a kind of information-transmitting art and a popular propaganda tool. Poster design shall have considerable appeal and artistic appeal. It should use image, color, graphics, sense of form and other factors to form a strong visual effect. Its picture shall be given with a strong visual center. It should seek to be novel, simple, and possess a unique artistic style and design features". The internationally renowned designer Wang $\mathrm{Xu}$ integrated Chinese traditional culture essence into the modern design concepts through his design works, greatly improving the status of Chinese design in the world. The elements of calligraphic art in his design show the essence of traditional culture and the combination of traditional art and modern design very well. The poster design works of Wang Xu have applied Chinese traditional cultural elements, which brought Chinese design in line with international level gradually, meanwhile find a direction for the international development of Chinese design. In the process of inheritance of traditional culture and innovation, he gradually formed his own unique design language.

The Japanese design also pay attention to the application of traditional art. The Japanese design has applied their 
traditional calligraphic art into poster design, creating designs with Japanese characteristics. The official poster of the 2002 World Cup in Japan and South Korea issued by FIFA in 2002 was designed by the artists of Japan and South Korea. It vividly depicts the image of the football field through the traditional calligraphic art. FIFA President Blatter said "this design is unique, elegant, and very suitable for the propaganda of such a FIFA World Cup holding by two different countries in Asia for the first time". The designers of South Korean also integrates traditional elements into poster design, so that their design works are endowed with Korean ethnic characteristics.

\section{THE APPLICATION OF TRADITIONAL CALLIGRAPHIC ART IN BOOK DESIGN}

"Book design is a book modeling art. It covers a serious of design activities, including arrangement of book structure, application of form and material, printing processing, binding processing and etc., in the publishing course. It is an overall design on covers, pastedown, title page, preface, catalog, text style, text, communication style, rhythm, gradation, image, blank, decoration, line, mark, page number and other elements". Book design and calligraphy are all arts with text as carrier, so there must be a line between them. The calligraphic art has played a very important role in the application of book design. Today, the calligraphic art is more and more widely applied in book design, because designers have realized that it can reveal the cultural charm only and simply by combining traditional culture with modern design. Tradition and modernity, nation and world have become topics widely reflected and discussed in modern art circle. Currently, the consensus that the Chinese design circle has reached is that to achieve localization, we cannot abandon the traditional culture; to realize internationalization, we should insist on our national characteristics.

Book design designers can draw nourishment from the art of calligraphy in order to show the unique national culture and national temperament. The book design of " $\mathrm{Zhu} \mathrm{Xi}$ Calligraphy" designed by the international famous book designer, Lv Jingren, Professor of the Academy of Fine Arts of Tsinghua University, has achieve the unity of content and form, and well reflects our national characteristics. His book design, applied the Chinese traditional calligraphic elements, well embodies the Chinese traditional culture. The Chinese traditional elements applied by designer are good interpretation of the contents of the book. The cover design uses the basic strokes of Chinese calligraphy dot, left falling and right falling as basic notation features in Volume 1, Volume 2 and Volume 3, which unify the format and is endowed with personality. It adopts special techniques and distinct features, and closely keeps to the point. Through appropriate processing, they are clearly showed to readers. It can attract readers attention and arouse readers' visual interest, thus achieve the purpose of design. The covers and poster design of "Tianya", designed by the famous designer Han Jiaying for a large-scale literary magazine, has used Chinese characters as his design elements. He creates a new visual effect by innovative combination design. His works express deep cultural connotations and influence the aesthetic level of the mass, change the traditional design style of magazine, and won the Bronze Award of the Sixth Toyama International Poster Triennial Exhibition in Japan.

In short, through these outstanding design cases we can see the flexible application of traditional calligraphic elements in graphic design and appreciate the classical beauty in modern design works. We can see the artistic beauty of calligraphy in logo design, book design and poster design and etc.. In above cases, the application of basic strokes of calligraphic art highlights the individual beauty of design work. The application of different calligraphic fonts in graphic design enhances the visual effect. The application of ink elements in graphic design reveals the profound cultural connotation in design works and reflects the internationalization of design works. We can see the application of dot and line, stroke, ink and other traditional elements in logo, book, packaging and poster and other designs. We can feel the charm of the traditional calligraphic art in different design works, which reflects the localization and internationalization of graphic design. Therefore, only by combing the traditional culture and modern design, can we add national characteristics to design works, improve overall level of our graphic design and form the graphic design style with Chinese characteristics.

\section{REFERENCES}

[1] Deng Xiaopeng. Calligraphy Application in Visual Arts. Hangzhou: China Academy of Art Press, 1988.

[2] Chen Nan. Logo Design. Beijing: China Youth Press, 2006.

[3] Chen Lei. Packaging Design. Beijing: China Youth Press, 2006.

[4] Li Yanzu, Lu Ying. Plane Design Art. Beijing: Chinese People's Publishing House, 2005.

[5] Zou Jiamian. 50 Poster Design Masters. Wuhan: Hubei Fine Arts Publishing House, 2006.

[6] Zhu Qiying. Poster Design. Beijing: Chinese Architecture Industry Press, 2009.

[7] Wang Yanfa. Principles of Visual Communication Design. Shanghai: Higher Education Press, 2008.

[8] Ni Jianlin. Comparison of Chinese Design and Western Design. Chongqing: Chongqing University Press, 2007. 